Original Contribution

\title{
THE BALKAN ENDEMICS MOEHRINGIA JANKAE GRISEB. EX JANKA AND MOEHRINGIA GRISEBACHII JANKA IN SINITE KAMANI NATURAL PARK, BULGARIA
}

\author{
N. Grozeva ${ }^{1}$, M. Gerdzhikova ${ }^{1}$, M. Todorova ${ }^{1}$, G. Panayotova ${ }^{1}$, D. Dohchev ${ }^{2}$, \\ K. Tsutsov ${ }^{2}$
}

${ }^{1}$ Faculty of Agriculture, Trakia University, Stara Zagora, Bulgaria

${ }^{2}$ Sinite Kamani Natural Park, Sliven, Bulgaria

\begin{abstract}
The aim of the study is to establish the current distribution of Moehringia jankae Griseb. ex Janka and Moehringia grisebachii Janka in Sinite Kamani Natural Park and to assess the state of its populations. Nine populations of $M$. jankae and fourteen populations of $M$. grisebachii were registered. It has been established that the Balkan endemic $M$. jankae inhabits quartz porphyry rock formations, conglomerates and limestones in Karandila, Haidushka pateka, Kaloyanovi kuli, Kamilata areas at an altitude of 590 to $972 \mathrm{~m}$. Its populations number from 10 to 72 specimens at an area of 0.5 to $796 \mathrm{~m}^{2}$. The Balkan endemic M. grisebachii inhabits quartz porphyry rock formations and conglomerates in Haidushka pateka, Mollova kuria, Kaloyanovi kuli, Karandila, Gornaka, Karakyutyuk, Kamilata and Golyama Chatalka at an altitude from 641 to $1049 \mathrm{~m}$. Its populations number from 11 to about 347 specimens on an area of 1.7 to $1720 \mathrm{~m}^{2}$. Main threats to the populations of both species in the Natural Park are anthropogenic impact and adverse weather conditions during fruiting.
\end{abstract}

Key words: Moehringia jankae, Moehringia grisebachii, Sinite Kamani Natural Park, distribution

\section{INTRODUCTION}

The state of Bulgarian flora in recent decades is changing rapidly and dynamically in parallel with the changes in the environment. Havens for biodiversity conservation are the protected areas. One of them is Sinite Kamani Natural Park, located on the southern slopes of Eastern Balkan Range above the town of Sliven. The alternating majestic forests, spacious meadows, glades and unique rock formations on the territory of the park are full of interesting plants. Until now over 1060 vascular plants have been established for the park (1-5), among which 32 endemics, 2 tertiary relics and 42 protected species.

The object of the present study was two of the Bulgarian endemics established for the park Moehringia jankae Griseb and Moehringia grisebachii Janka. The distribution area of two species comprises Bulgaria and Romania (Northern Dobrudzha), M. grisebachii being noted for European Turkey as well (6-9). More scarcely distributed in the country is $M$.

\footnotetext{
*Correspondence to: Neli Grozeva, e-mail: grozeva@uni-sz.bg, +35942699 317, Faculty of Agriculture, Trakia University, 6000 Stara Zagora, Bulgaria
}

jankae. It is found on rock formations in North-eastern Bulgaria (Shumen region), Balkan Range (Eastern - Sinite Kamani Natural Park); from 500 to 1050 m a.s.l. (6-7, $9)$. The species is protected by the Biogical Dioversity Act (10), included in the Red Book of Bulgaria, vol. 1. Plants and fungi in category „endangered" (9). It is protected by the Bern Conservation (11) and according to the criteria of the IUCN Red Lists of Threatened Plants (12) it has been rated as „Data Deficient (DD)” on a global scale. $M$. grisebachii is found in rocky habitats in Northeast Bulgaria, Balkan Range (Eastern Sinite Kamani Natural Park), Sredna Gora Mts (Western and Eastern), Thracian Lowland (northwards of the village of Matochina, Svilengrad district), Tundzha Hilly Country (Sakar Mt); from 0 to $900 \mathrm{~m}$ a.s.l. (6-8). The species is included in the Red Book of Bulgaria, vol.1. Plants and fungi in category „endangered” (8). The two Balkan endemics are mentioned for the territory of Sinite Kamani Natural Park by Andreev (13), in relation to developing the forest management plan. Grozeva et al. (1) registered two populations of $M$. grisebachii and three populations of $M$. jankae on the rocky habitats 
GROZEVA N., et al.

in Karandila area. The populations number between 35-70 specimens.

The objective of the present study is to establish the present-day distribution of $M$. jankae and $M$. grisebachii on the territory of Sinite Kamani Natural Park, to assess the state of their populations in the park and to suggest measures for their conservation and stability. The study is a part of the project "Restoration of habitats and protection of biodiversity in Sinite Kamani Natural Park".

\section{MATERIALS AND METHODS}

The study was conducted during the vegetation periods of 2013-2015. The average annual temperature in the region of the town of Sliven, calculated for a multi-year period is $12.4^{\circ} \mathrm{C}$. In the three years of the study the average annual temperature is higher than the multi-year period by over $1{ }^{\circ} \mathrm{C}\left(13,8{ }^{\circ} \mathrm{C}\right.$ in $2013,13,5^{\circ} \mathrm{C}$ in $2014,13,7^{\circ} \mathrm{C}$ in 2015$)$.

The annual rainfall in the studied area is 600 $\mathrm{mm}$ average for the multi-year period. In 2013 the amount of rainfall was by $17.6 \%$ lower. It is unusually high in $2014-70.6 \%$ higher than the typical for the area. Rainfall is more in the third year of the study by $16.2 \%$.

The formation "Sinite Kamani" consists of acidic quartz porphyry rocks. In the northern and western part of the formation and carbonate sedimentary rocks spread in a fingershape in quartz porphyry region: dolomites, limestone, shale and conglomerates.

To establish the distribution of species the routing method was applied. The tourist routes in the park were mainly used with more or less deviations in order to cover as much as possible of the habitats characteristic for each species. Studies have been carried out mainly on the following routes: Karandila area Kushbunar area - Peschenik peak - Enyova bulka area - Kaloyanovi kuli area - Mollova kuria area, Karandila area - Chukata area Enyova bulka area - TV Tower - Karandila Hotel complex; Mollova kuria area - Upper lift station - Karandila area; Town of Sliven Haiduschka pateka area - Kamilata area Karandila area; Town of Sliven - Plachi dol area - Barmuka peak - Ablanovo area; Ablanovo area - Bobenishteto area - Asenovets Dam, Karandila area - Gornaka area Kafedziiski kainak area - Peschenik peak Karandila area; Karandila area - Ravna reka area - Golyama Chatalka area - Belite izvori area - Tyutyunlyuka area - Lower Lift Station; Kushbunar - Karandila area - TV Tower Maryova skala area; Ablanovo area - Dalgia rid area; Ablanovo area - Plochite area Ovcharnitsite area - Karakyutyuk area Kostova cheshma area - Balgarka peak - Daula area; Town of Sliven - Slancheva polyana area - Karandila area - Microdam, Mollova kuria area - Gornaka area - Karandila area - Mecha polyana area; Town of Sliven - Gagovets area, Town of Sliven - Novoselska River - Kuru Dere area, Ayazmoto area - Malka polyana area - Aremiyata area, Sliven - turnout to the village of Sotirya - Andreeva cheshma Hisarlaka, Karandila area - Chukata area Malkata chuka - Tunkata rutlina - Lokvata. A Global positioning system (GPS) was used to determine the coordinates of the sampling points. The habitats of the species are presented on the map using Google Earth. The registered populations were visited during phenophase reaching normal size of leaves, beginning of flowering, flowering, fruit formation, fruit bearing, falling of mature seeds and period after falling of leaves.

To assess the status of each population Methodology for monitoring vascular plants in Bulgaria has been used. The voucher specimens are deposited in the herbarium of the Institute for Biodiversity and ecosystem research Bulgarian Academy of Sciences (SOM).

\section{RESULTS AND DISCUSSION Moehringia jankae}

As a result of terrain studies 9 populations of $M$. jankae were established on the park territory (Figure 1). Four of the populations are in Karandila area - rock formation $350 \mathrm{~m}$ south of Karandila Hotel complex, rock formation $450 \mathrm{~m}$ south-west of Karandila Hotel complex, on the rocks around Karandilska polyana and on the high eastern rocks around the Microyazovir area; three of them on Haidushka pateka - on the rocks around the path, to the south of Karandila Hotel complex and east of Karandila Hotel complex in the direction of Sliven. The other two populations are in Kaloyanovi kuli area and Kamilata area.

The population on a rock formation $350 \mathrm{~m}$ south of Karandila Hotel complex is located on the northern side of vertical quartz porphyry rocks at an altitude of $933 \mathrm{~m}$ on an area of 1.5 $\mathrm{m}^{2}$. The geographical coordinates in its central part are $\mathrm{N} 42^{\circ} 42.738^{\prime}$, E $26^{\circ} 22.360^{\prime}$. The plant community is dominated by lichens and mosses. Its number during the three-year study period increased from 2 to 10 specimens.

The population on a rock formation $450 \mathrm{~m}$ south-west of Karandila Hotel complex is 
located on the southern side of vertical conglomerates at an altitude of $908 \mathrm{~m}$ on an area of $55 \mathrm{~m}^{2}$. The geographical coordinates in its central part are $\mathrm{N} 42^{\circ} 42.704^{\prime}$, E $26^{\circ}$
GROZEVA N., et al. $22.254^{\prime}$. The plant community is dominated by lichens and mosses. Its number increased from 47 to 56 specimens during the study period.

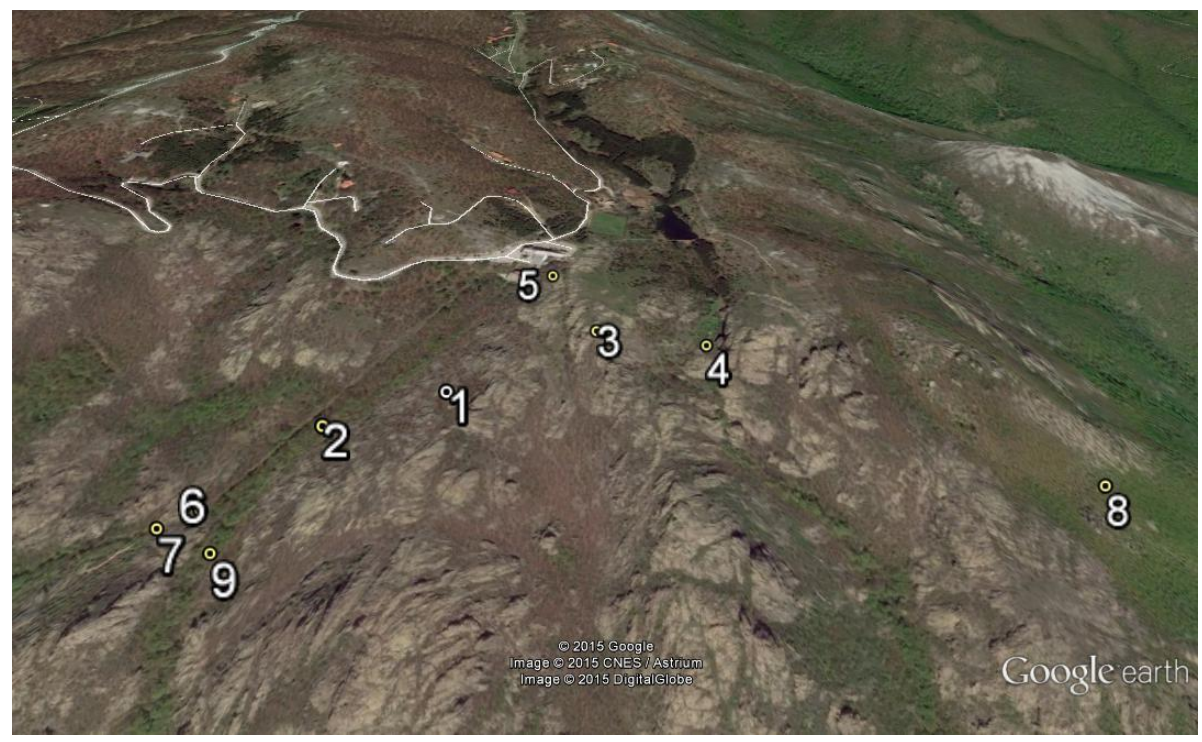

Figure 1. Distribution of Moechringia jankae Griseb. in Sinite Kamani Natural Park: 1. $350 \mathrm{~m}$ south of Karandila Hotel complex; 2. 450 m south-west of Karandila Hotel complex; 3.

Karandilska polyana area; 4. Microyazovir area; 5. Haidushka pateka - north; 6. Haidushka pateka - south; 7. Haidushka pateka - west; 8. Kaloyanovi kuli area; 9. Kamilata area.

The population on the rocks around Karandilska polyana is located on the southern side of vertical quartz porphyry rocks at an altitude of $955 \mathrm{~m}$ on an area of $796 \mathrm{~m}^{2}$. The geographical coordinates in its central part are $\mathrm{N} 42^{\circ} 42.873^{\prime}$, E $26^{\circ} 22.452^{\prime}$. The plant community is dominated by lichens and mosses. An accompanying conservation significant species is Moehringia grisebachii. The number of the population increased from 35 to 61 specimens during the study period.

The population on the high eastern rocks around the Microyazovir area is located on the western and north-western side on vertical quartz porphyry rocks at an altitude of $972 \mathrm{~m}$ at an area of $25.5 \mathrm{~m}^{2}$. The geographical coordinates in its central part are $\mathrm{N} 42^{\circ}$ $42.790^{\prime}$, E $26^{\circ} 22.612^{\prime}$. The plant community is dominated by lichens and mosses. An accompanying conservation significant species is $M$. grisebachii. The population was registered during the vegetation period of 2014. During the two-year study period its number increased from 16 to 19 specimens.

The population on the rocks around Haidushka pateka is located on the eastern, western and southern sides of vertical quartz porphyry rocks at an altitude of 590-621 m at an area of $20.3 \mathrm{~m}^{2}$. The geographical coordinates in its central part are $\mathrm{N} 42^{\circ} 42.873^{\prime}$, E $26^{\circ} 22.452^{\prime}$. The plant community is dominated by lichens and mosses. The number of the population during the three-year study period increased from 64 to 72 specimens.

The population from Haidushka pateka to the south of Karandila Hotel complex is located on the western side of vertical conglomerates at an altitude of $879 \mathrm{~m}$ on an area of $0.5 \mathrm{~m}^{2}$. The geographical coordinates in its central part are $\mathrm{N} 42^{\circ} 42.652^{\prime}$, E $26^{\circ} 22.158^{\prime}$. The plant community is dominated by lichens and mosses. The number of the population during the three-year study period increased from 12 to 17 specimens.

The population from Haidushka pateka to the east of Karandila Hotel complex is located on the north-western side of vertical quartz porphyry rocks at an altitude of $857 \mathrm{~m}$ on an area of $1.3 \mathrm{~m}^{2}$. The geographical coordinates in its central part are $\mathrm{N} 42^{\circ} 42.640$, E $26^{\circ}$ $22.125^{\prime}$. The plant community is dominated by lichens and mosses. The number of the population during the three-year study period increased from 4 to 7 specimens.

The population from Kaloyanovi kuli area is located on the western side of vertical quartz porphyry rocks at an altitude of $756 \mathrm{~m}$ on an area of $19 \mathrm{~m}^{2}$. The geographical coordinates in its central part are $\mathrm{N} 42^{\circ} 42.755$, E $26^{\circ}$ $23.015^{\prime}$. The plant community is dominated by lichens and mosses. The number of the population during the three-year study period increased from 38 to 48 specimens. 
The population from Kamilata area is located on the eastern and southern sides of vertical quartz porphyry rocks at an altitude of $857 \mathrm{~m}$ on an area of $4.3 \mathrm{~m}^{2}$. The geographical coordinates in its central part are $\mathrm{N} 42^{\circ} 42.601$, E $26^{\circ} 22.183^{\prime}$. The plant community is dominated by lichens and mosses. An accompanying conservation significant species is M. grisebachii. The population was established during the vegetation period of 2014. Its number during the two-year study period increased from 27 to 31 specimens.

The registered 9 populations of $M$. jankae are in relatively good condition. As is evident on Figure 2, during the study period an increase in number was registered in all populations, more pronounced in the vegetation period of 2014. This increase, according to our observations, is most probably due to the wetter spring and summer and the more abundant moisture allowed for the majority of mature seeds that had fallen in rock crevices to develop successfully. The observed increase in number is far from the theoretically possible since the seed productivity of a single plant reaches 40 seeds. Major threats to the populations of $M$. jankae in the park are anthropogenic impact and adverse weather conditions during flowering and fruiting of the species.

Moehringia jankae

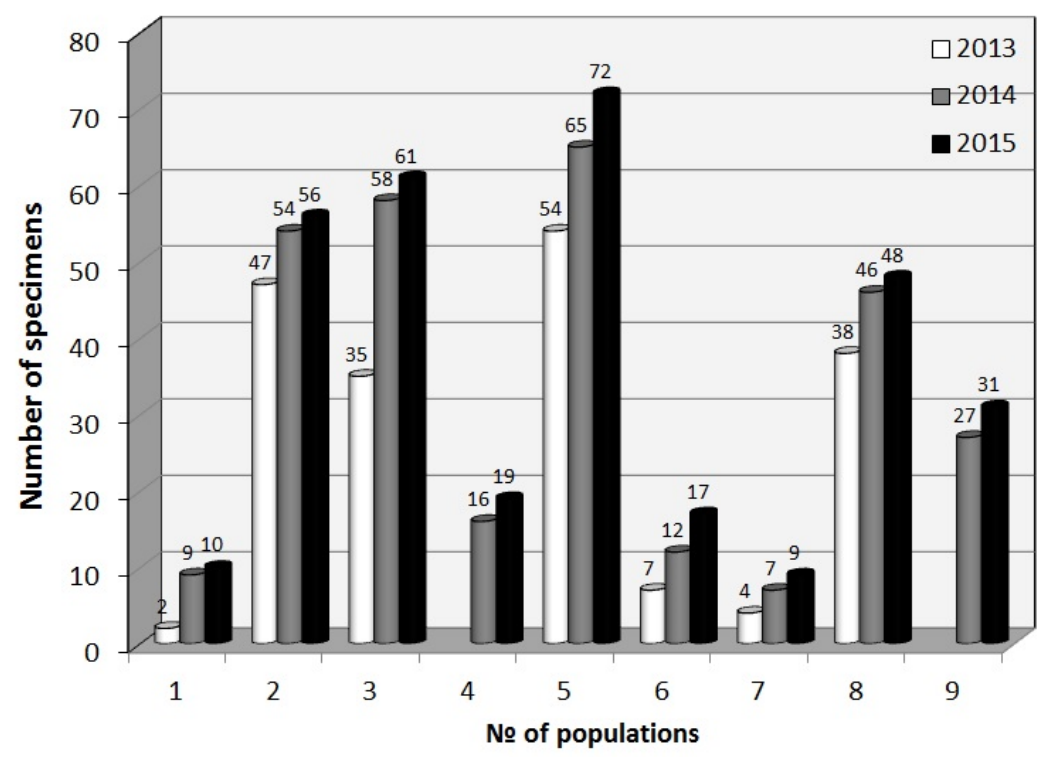

Figure 2. Abundance of registered populations of Moechringia jankae Griseb during the vegetation period of 2013-2015: 1. 350 m south of Karandila Hotel complex; 2. 450 m south-west of Karandila Hotel complex; 3. Karandilska polyana area; 4. Microyazovir area; 5. Haidushka pateka - north; 6. Haidushka pateka - south; 7. Haidushka pateka - west; 8. Kaloyanovi kuli area; 9. Kamilata area.

\section{Moehringia grisebachii}

As a result of terrain studies 14 populations of $M$. grisebachii were established on the park territory (Figures 3 and 4). Three populations were registered near Haidushkata pateka - on rocks formations around the path, southeast and east of it. In the immediate vicinity and in Mollova kuria area 3 populations of the species have also been found - east and west of the marked trail to the area and at the bend of the path from Mollova kuria area to Gornaka area. Two populations have been registered for each of the areas Kaloyanovi kuli and Karandila and one population in the areas Gornaka, Karakyutyuk, Kamilata and Golyama Chatalka.

The population on the rock formations around Haidushka polyana is located on the eastern side of vertical conglomerates at an altitude of $641 \mathrm{~m}$ at an area of $14 \mathrm{~m}^{2}$. The geographical coordinates in its central part are $\mathrm{N} 42^{\circ} 42.290$,
E $26^{\circ} 21.655^{\prime}$. The plant community is dominated by lichens and mosses. During the three-year study period the number of the population increased from 17 to 26 specimens. The population to the south-east of Haidushka pateka is located on the southern side of vertical conglomerates at an altitude of $951 \mathrm{~m}$ at an area of $12 \mathrm{~m}^{2}$. The geographical coordinates in its central part are $\mathrm{N} 42^{\circ} 42.828$, E $26^{\circ} 22.432^{\prime}$. The plant community is dominated by lichens and mosses. During the three-year study period the number of the population increased from 15 to 22 specimens.

The population to the east of Haidushka pateka is located on the south-eastern side of vertical quartz porphyry rocks at an altitude of $921 \mathrm{~m}$ at an area of $25 \mathrm{~m}^{2}$. The geographical coordinates in its central part are $\mathrm{N} 42^{\circ} 42.782$, E $26^{\circ} 22.348^{\prime}$. The plant community is dominated by lichens and mosses. 


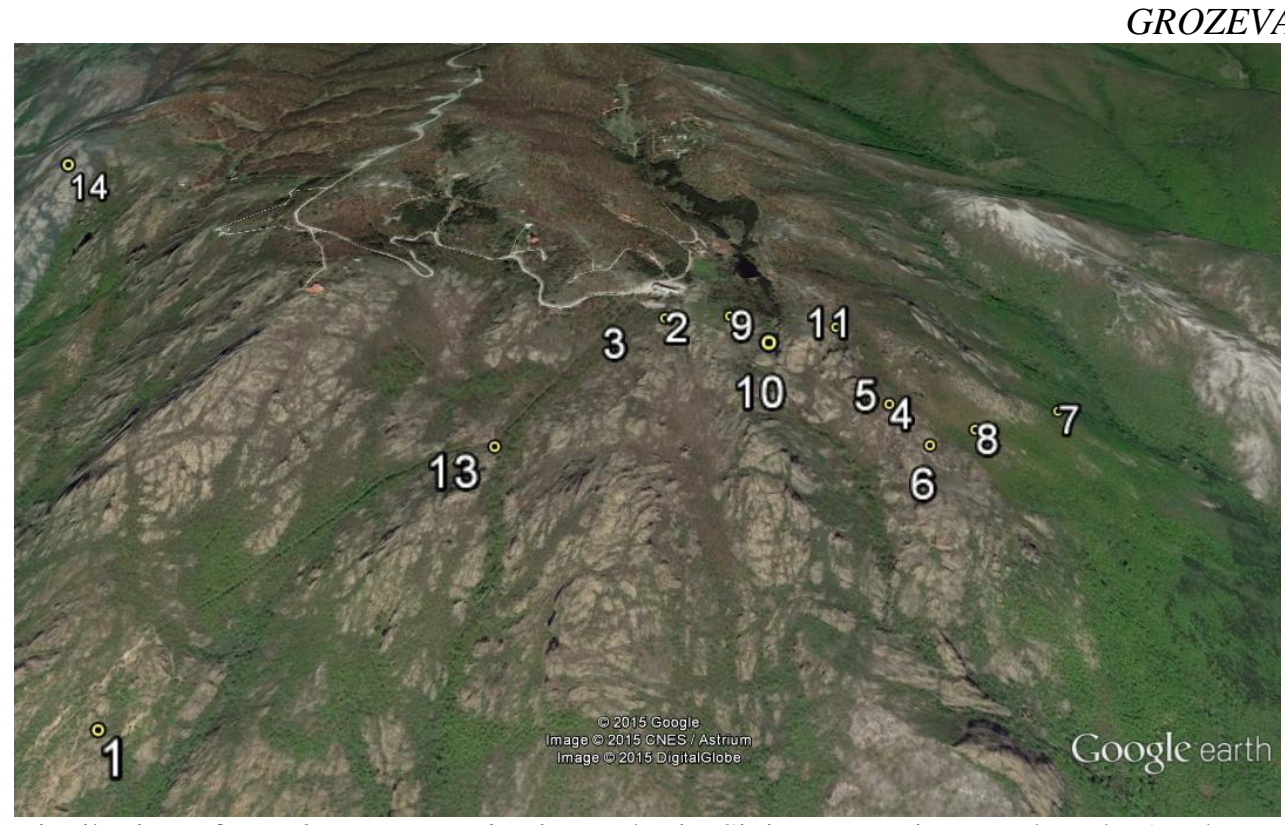

Figure 3. Distribution of Moehringia grisebachii Janka in Sinite Kamani Natural Park: 1. The south part of Haidushka pateka; 2. South-east of Haidushka pateka; 3. East of Haidushka pateka; 4. East of Mollova kuria area; 5. To Mollova kuria area; 6. Mollova kuria area; 7. To Kaloyanovi kuli area; 8. Kaloyanovi kuli area before Kafedziiski kainak; 9. Karandilska polyana area; 10. Around Microyazovir area; 11. Gornaka area; 13. Kamilata area; 14. Golyama Chatalka area.

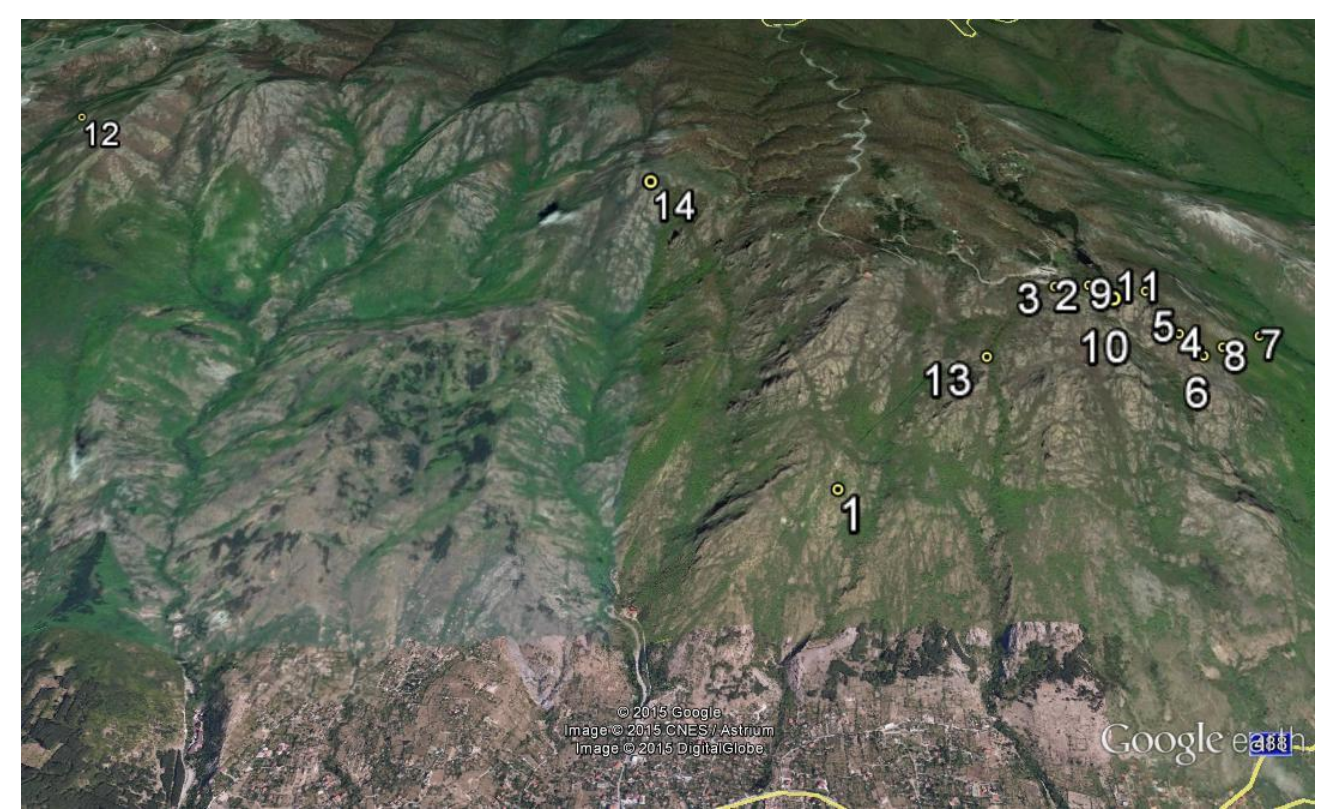

Figure 4. Distribution of Moehringia grisebachii Janka in Sinite Kamani Natural Park: 12. Karakyutyuk area.

During the three-year study period the number of the population increased from 14 to 26 specimens.

The population to the east of the marked trail to Mollova kuria area is located on the western side of vertical quartz porphyry rocks at an altitude of $830 \mathrm{~m}$ at an area of $3.5 \mathrm{~m}^{2}$. The geographical coordinates in its central part are $\mathrm{N} 42^{\circ}$ 42.727, E $26^{\circ}$ 22.813'. The plant community is dominated by lichens and mosses. During the three-year study period the number of the population increased from 6 to 14 specimens.
The population to the west of the marked trail to Mollova kuria area is located on the western side of vertical limestone at an altitude of 830 $\mathrm{m}$ at an area of $16 \mathrm{~m}^{2}$. The geographical coordinates in its central part are $\mathrm{N} 42^{\circ} 42.727$, E $26^{\circ} 22.800^{\prime}$. The plant community is dominated by lichens and mosses. During the three-year study period the number of the population increased from 11 to 22 specimens.

The population from the rock formations at the bend of the trail from Gornaka area to Mollova kuria area is located on the eastern side of vertical quartz porphyry rocks at an altitude of $803 \mathrm{~m}$ at an area of $15.3 \mathrm{~m}^{2}$. The geographical 
GROZEVA N., et al.

coordinates in its central part are $\mathrm{N} 42^{\circ} 42.664$, E $26^{\circ} 22.869^{\prime}$. The plant community is dominated by lichens and mosses. During the three-year study period the number of the population increased from 15 to 24 specimens.

The population from the rock formations around the junction to Kaloyanovi kuli area above the panel is located on the southern side of vertical quartz porphyry rocks at an altitude of $685 \mathrm{~m}$ at an area of $1.7 \mathrm{~m}^{2}$. The geographical coordinates in its central part are $\mathrm{N} 42^{\circ} 42.833$, E $26^{\circ} 23.169^{\prime}$. The plant community is dominated by lichens and mosses. During the three-year study period the number of the population increased from 4 to 11 specimens.

The population from the rock formations in Kaloyanovi kuli area - before the junction to Kafedziiski kainak is located on the southeastern side of vertical quartz porphyry rocks at an altitude of $770 \mathrm{~m}$ at an area of $12 \mathrm{~m}^{2}$. The geographical coordinates in its central part are $\mathrm{N} 42^{\circ} 42.720$, E $26^{\circ} 22.968^{\prime}$. The plant community is dominated by lichens and mosses. During the three-year study period the number of the population increased from 17 to 28 specimens.

The population from Karandila area - around Karandilska polyana is located on the northern and north-eastern side of vertical quartz porphyry rocks at an altitude of 994-998 $\mathrm{m}$ at an area of $1720 \mathrm{~m}^{2}$. The geographical coordinates in its central part are $\mathrm{N} 42^{\circ} 42.833$, E $26^{\circ} 22.525^{\prime}$. The plant community is dominated by lichens and mosses. An accompanying conservation significant species is $M$. jankae. The population was registered during the vegetation period of 2014. During the two-year study period its number increased from 330 to 347 specimens.

The population from the high eastern rocks near the Microyazovir area is located on the western and north-western side of vertical quartz porphyry rocks at an altitude of $975 \mathrm{~m}$ at an area of $25.5 \mathrm{~m}^{2}$. The geographical coordinates in its central part are $\mathrm{N} 42^{\circ}$ $42.480^{\prime}$, E $26^{\circ} 22.423^{\prime}$. The plant community is dominated by lichens and mosses. An accompanying conservation significant species is $M$. jankae. The population was registered during the vegetation period of 2014. During the two-year study period its number increased from 41 to 45 specimens.
The population in Gornaka area is located on the western side of vertical quartz porphyry rocks at an altitude of $920 \mathrm{~m}$ at an area of 60 $\mathrm{m}^{2}$. The geographical coordinates in its central part are $\mathrm{N} 42^{\circ} 42.828^{\prime}$, E $26^{\circ} 23.735^{\prime}$. The plant community is dominated by lichens and mosses. During the three-year study period the number of the population increased from 4 to 17 specimens.

The population from Karakyutyuk area is located on the western side of vertical limestone at an altitude of $851-854 \mathrm{~m}$ at an area of $4.7 \mathrm{~m}^{2}$. The geographical coordinates in its central part are $\mathrm{N} 42^{\circ} 43.861^{\prime}$, E $26^{\circ}$ $18.662^{\prime}$. The plant community is dominated by lichens and mosses. During the three-year study period the number of the population increased from 10 to 22 specimens.

The population from Kamilata area is located on the western side of vertical conglomerates at an altitude of $838 \mathrm{~m}$ at an area of $17.5 \mathrm{~m}^{2}$. The geographical coordinates in its central part are $\mathrm{N} 42^{\circ} 42.595^{\prime}$, E $26^{\circ} 22.179^{\prime}$. The plant community is dominated by lichens and mosses. An accompanying conservation significant species is $M$. jankae. The population was registered during the vegetation period of 2014. During the two-year study period its number increased from 21 to 28 specimens.

The population from Golyama Chatalka area is located on the western side of vertical quartz porphyry rocks at an altitude of 1022-1049 m at an area of $29.5 \mathrm{~m}^{2}$. The geographical coordinates in its central part are $\mathrm{N} 42^{\circ}$ $43.362^{\prime}$, E $26^{\circ} 21.093^{\prime}$. The plant community is dominated by lichens and mosses. The population was registered during the vegetation period of 2014. During the two-year study period its number increased from 21 to 25 specimens.

The registered 14 populations of $M$. grisebachii are in good condition. During the study period increase in number was established and it was the most significant in 2014 (Figure 5), which is probably related to the wetter spring and summer, which allowed the mature seeds to attach to and develop on the rock formations. The observed increase in number is far from the theoretically possible since the seed productivity of a single plant reaches 40 seeds. Major threats to the populations of the species in the park are anthropogenic impact and adverse weather conditions during flowering and fruiting. 


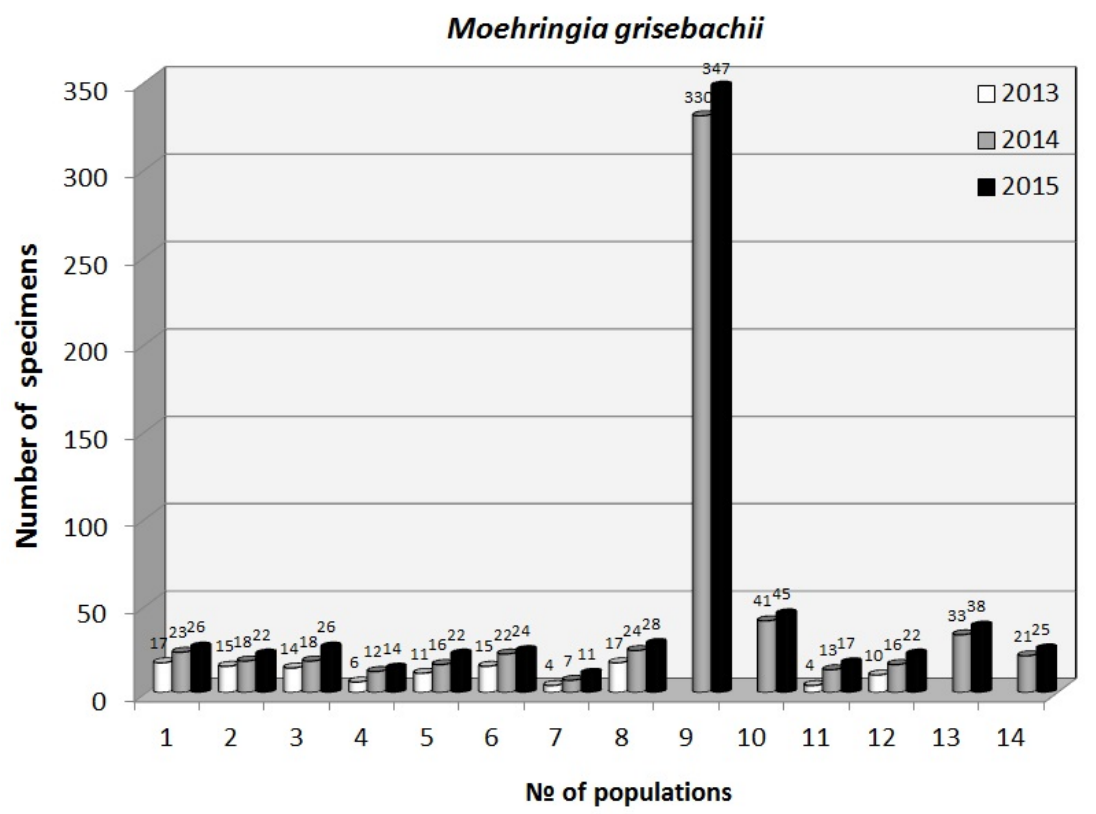

Figure 5. Abundance of registered populations of Moehringia grisebachii Janka during the vegetation period of 2013-2015: 1. The south part of Haidushka pateka; 2. South-east of Haidushka pateka; 3. East of Haidushka pateka; 4. East of Mollova kuria area; 5. To Mollova kuria area; 6. Mollova kuria area; 7. To Kaloyanovi kuli area; 8. Kaloyanovi kuli area before Kafedziiski kainak; 9. Karandilska polyana area; 10. Around Microyazovir area; 11. Gornaka area; 12. Karakyutyuk area, 13. Kamilata area; 14. Golyama Chatalka area.

Opportunities for in-situ and ex-situ conservation of $M$. jankae and M. grisebachii The survey data indicate that at this stage it would be inappropriate to apply in-situ measures in order to support the seedling regeneration of $M$. jankae and $M$. grisebachii, due to the extreme fragility and brittleness of the flower stalks of plants as well as the lack of knowledge concerning the mechanisms of distribution, attachment and growth of the mature seeds. Our observations show that at the end of the flowering phenophase the flower stalks of all specimens twist and flowers, and later fruits, turn towards the rocks. Most likely this allows the mature seeds fall easily on the rocks when the fruits open. However, the mechanism for attaching the seeds to the rocks is unknown. The fact is that a very small part of the mature seeds find favorable conditions for their development. Possible reasons for this, according to our observations, are the adverse weather conditions during fruiting, since stronger winds and/or heavy rain, for example, would carry the mature seeds into habitats unfavorable for their development. Prolonged drought, low winter temperatures could also hinder seed regeneration. The application of $e x$-situ measures, due to the appertaining of both species to a specific habitat (rocks), is also inappropriate.

At this stage, efforts should be aimed at limiting access to the populations of M. jankae and $M$. grisebachii in the park, for example in the cases when making tourist routes and/or organising sports and other events. It is difficult to protect species which are not well known, therefore in future publications of Sinite Kamani Natural Park data and photos of these species should be included, so that fans of rock climbing, sports orientation, etc. will become familiar with them and their conservation significance. Since the majority of the populations of both species are in some of the places most visited by tourists such as Karandila and Haidushka pateka, it is imperative to put their photos on the panels with protected species on the park territory.

\section{CONCLUSION}

The Balkan endemic $M$. jankae forms populations on the territory of Sinite Kamani Natural Park on quartz porphyry rock formations and conglomerates in Karandila, Haidushka pateka, Kaloyanovi kuli, Kamilata areas at an altitude of 590 to $972 \mathrm{~m}$. Populations number from 10 to 72 specimens at an area of 0.5 to $796 \mathrm{~m}^{2}$. Dominant in the $M$. jankae populations are lichens and mosses. An accompanying conservation significant species in a three of the registered populations is $M$. grisebachii.

Balkan endemic $M$. grisebachii forms populations on the territory of Sinite Kamani Natural Park on quartz porphyry rock formations, conglomerates, sandstones and limestones in Haidushka pateka, Mollova kuria, Kaloyanovi kuli, Karandila, Gornaka, Karakyutyuk, Kamilata and Golyama Chatalka at an altitude from 641 to $1049 \mathrm{~m}$. Populations 
GROZEVA N., et al.

number from 11 to about 347 specimens on an area of 1.7 to $1720 \mathrm{~m}^{2}$. Dominant in the $M$. grisebachii populations are lichens and mosses. An accompanying conservation significant species in a three of the registered populations is $M$. jankae.

Main threats to the populations of both species in the Natural Park are anthropogenic impact and adverse weather conditions during fruiting. Their appertaining to a specific habitat and the lack of data on the mechanisms for distribution, attachment and development of seeds do not allow at this stage to undertake specific in-situ and/or ex-situ measures for their seed regeneration. Efforts should be aimed at limiting access to their habitats and including them in panels, electronic and printed publications of Sinite Kamani Natural Park.

\section{ACKNOWLEDGEMENT}

This work was financially supported under contract No OPOS 2-36 / 24.07.2013 to project No 5103020-15-658 for Sinite Kamani Natural Park, funded under contract No 5103020-C002 OPERATIONAL PROGRAMME "ENVIRONMENT 2007-2013“.

\section{REFERENCES}

1. Grozeva, N., Georgieva, M. and Vulkova, M., Flowering plants and ferns. In: Stoeva, M. (ed.), Biological diversity of Sinite Kamani Nature Park. Kontrast Bogomilovo, Stara Zagora, pp 9-112, 2004 (Bg).

2. Georgieva, M. and Petrova, A., Orchids in Sinite kamani Natural park. Rodina, Sofia, 2009 (Bg).

3. Petrova, A. S., Trifonov, G., Venkova, D. and Ivanova, M., Reports 51-74. - In: Vladimirov, V. \& al. (comps). New floristic records in the Balkans: 10. - Phytol. Balcan., 15(1): 115-139, 2009.

4. Petrova, A. S., Getova, N., Grozeva, N. and Venkova, D., Reports 73-93. - In:
Vladimirov, V. \& al. (comps). New floristic records in the Balkans: 17. - Phytol. Balcan., 17(3): 361-384, 2011.

5. Tashev. A., Reports 108-113. - In: Vladimirov, V. \& al. (comps). New floristic records in the Balkans: 17. - Phytol. Balcan., 17(3): 361-384, 2011.

6. Delipavlov, D., Cheshmedzhiev, I. (eds), Key to the Plants of Bulgaria. Acad. Press Agrarian University, Plovdiv, 2003 (Bg).

7. Assyov, B., Petrova, A. (eds), 2012. Conspectus of the Bulgarian Vascular Flora. Distribution Maps and Floristic Elements. Fourth revised and enlarged edition. Bulgarian Biodiversity Foundation, Sofia (Bg).

8. Stoyanov, S., Moehringia grisebachii Janka. In: Peev, D. et all. (eds.) Red Data Book of the Republic of Bulgaria. Volume 1. Plants and Fungi. $B A S \& M o E W$, Sofia, pp 533, 2015.

9. Stoeva, M., Moehringia jankae Janka. In: Peev, D. et all. (eds) Red Data Book of the Republic of Bulgaria. Volume 1. Plants and Fungi. BAS \& MoEW, Sofia, pp 534, 2015.

10.Biological Diversity Act, Darzhaven Vestnik no. 77 from 9 August 2002, pp. 942. Amended in Darzhaven Vestnik no. 94 from 16 November 2007, 2002 (Bg).

11.Bern Convention. Convention on the Conservation of European Wildlife and atural Habitats. Appendix I. https://rm.coe.int/CoERMPublicCommonS earchServices/DisplayDCTMContent?docu mentId=0900001680304354, 1979 (accessed 08.09.2015).

12. The IUCN Red List of Threatened Species. Version 2015-4. Moehringia jankae http://www.iucnredlist.org/details/162378/0 (accessed 08.09.2015).

13.Andreev, N., Development Plan of Sinite Kamani National Park. Botanical Characterization, Agrolesproekt, Sofia, $1981(\mathrm{Bg})$. 